\title{
Pap Smears: Frequency of Gardnerella Vaginalis, Candida spp., Trichomonas Vaginalis and Pill Use or Copper Intrauterine Device Use
}

José Antonio Barreto Alves', Mariangela da Silva Nunes', Ricardo Fakhouri', Paulo Ricardo Saquete Martins-Filho', Maria do Carmo de Oliveira Ribeiro1, Thiago dos Santos Valença ${ }^{1}$, Alberto Correa de Vasconcellos ${ }^{1}$, Alanna Gleice Carvalho Fontes Lima', Patricia Oliveira Santos ${ }^{1}$, Murilo Marchioro1, Gladslene Goes Santos Frazão ${ }^{1}$, Andreia Centenaro Vaez ${ }^{1}$, Karine Vaccaro Tako ${ }^{1}$

\section{Abstract}

Objective: To verify the frequency of Gardnerella vaginalis, Candida sp. Trichomonas vaginalis in pap smears and the presence of these when using the copper intrauterine device or the oral contraceptive.

Method: The analysis of 119,312 examinations of women seen by the public health system in the Northeast region of Brazil from the period from January 2006 to December 2010. The variables analyzed were age, frequency of microorganisms, contraceptive use, type of contraception adopted correlated with the presence of microorganisms.

Results: The average age among the women was 33.4 \pm 11.15 years. The most frequent microorganism, Gardnerella vaginalis, was found in 16,137 examinations, followed by Candida spp. in Trichomonas vaginalis and the 12,661 in 2023. The use of oral contraceptives was found in 21,792 women, and these, showed the presence of Gardnerella vaginalis in 1054, Candida spp. and Trichomonas vaginalis in 687 in 133 tests. Regarding the use of use of copper intrauterine device, used by 18,894 women, the presence of Gardnerella vaginalis was detected in 964, Candida spp. and Trichomonas vaginalis in 595 in 122 of the cases.

Conclusion: The presence of microorganisms associated with contraceptive use is evident, in particular, Garnerella vaginalis which is more common in both kinds of contraception methods adopted by women.
1 Federal University of Sergipe, Aracaju, Sergipe, Brazil.

Contact information:

Jose Antonio Barreto Alves.

Address: Department of Nursing, Federal University of Sergipe, Sergipe, Brazil.

”antoniobalves@gmail.com

Keywords

Gardnerella Vaginalis; Intrauterine Device; Vaginitis; Abnormal Vaginal Flora; Vaginal Smears. 


\section{Introduction}

The normal vaginal microbiota, its interaction with the products of microbial metabolism, hormonal status and host immune response, are factors that promote the balance in the vaginal ecosystem [1]. The presence of women with genital tract infection caused by Gardnerella vaginalis, Candida spp. or Trichomonas vaginalis is frequent in gynecological medical offices and public health services [2, 3].

In this context, it is observed that bacterial vaginosis affects $30 \%$ of women in childbearing age, with asymptomatic prevalence and is associated mainly to the presence of Gardnerella vaginalis [4]. Vaginal candidiasis is developed when there is excessive proliferation of Candida spp. and it may be present even in acidic vaginal ph [5]. Trichomoniasis is considered a sexually transmitted disease, asymptomatic for most men, in contrast to what occurs with women, whose etiologic agent is the protozoan Trichomonas vaginalis [2].

The presence of these microorganisms in the vagina may be predominantly asymptomatic. Nevertheless, when symptoms are present, they can range from mild discomfort to severe complications such as infertility, spontaneous abortion, premature labor, pelvic inflammatory disease and pelvic endometritis $[6,7]$. The use of the copper intrauterine device, spermicides, intercourse frequency and the habit of using vaginal douches are considered risk factors for these infections. However, the use of barrier methods or oral contraceptives is protective against such illnesses [8].

There is no agreement for the most appropriate contraceptive method for women who have recurring infections in the genital tract [9]. Despite the problem, there are very few studies on the relationship between the use of contraceptives and the presence of infectious agents.

Although the Pap smear has been designed for recognition epithelial changes in the neoplastic or pre-neoplastic nature of the cervix, through it, one may suggest the presence of certain microbiological agents such as Garderella vaginalis, Candida spp. and Trichomonas vaginalis $[7,10]$. This technique is a valuable diagnostic tool, especially in places where technological resources are limited [11].

Thus, the possibility of severe complications among women colonized increases the importance of studies to identify the age group most likely to develop bacterial vaginosis, candidiasis and trichomoniasis, as well as to determine the most appropriate contraceptive method.

Prevalence studies can be an alternative to check for possible risk factors. This information may be used in the planning of assistance policies to women's health and hence, measures of prevention and treatment become more effective by reducing the proliferation of resistant microorganisms. The purpose of this study was to determine the frequency of Candida spp., Trichomonas vaginalis and Gardnerella vaginalis in Pap tests and the presence of the copper intrauterine device or oral contraceptive.

\section{Method}

This is a descriptive, cross-sectional study, using secondary data. We analyzed the information contained in preventive screening of the cervix smear collection, which took place in establishments that provide service to the public health system, the women's health attention program in the city of Aracaju, Northeast Brazil. With the performance of 133 family health teams, the city of Aracaju, is a reference in health services for other counties of the region and it has 43 institutions of primary health care, which have performed the Pap smear.

A number of 119,312 pap smears tests collected from January 2006 to December 2010 whose data were collected from the Database Information System for cervical cancer (SISCOLO), under the responsibility of the Municipal Health Department of that city, were analyzed. This system is designed 
to store the identification of women, demographic and epidemiological information, in addition to the results of cytopathology and histopathology tests performed by the Public Health System in Brazil.

All the information has been transferred, categorized and analyzed in computer database software program SPSS (Statistical Package for the Social Sciences) version 18.0, and presented in the form of tables, using the chi-square test to check for the level of significance between groups. The significance level of $5 \%$ was considered to the whole study.

The variables analyzed in this study were: frequency of Candida spp. Gardnerella vaginalis and Trichomonas vaginalis, the use of pills or the intrauterine device, average age of patients and type of contraception method associated with the presence of microorganisms.

This study was approved by the Ethics Committee in Research of the Federal University of Sergipe under no-CAAE 1292.0.000.107-11.

\section{Results}

Gardnerella vaginalis was the most common organism in all years investigated with 16,137 (13.52\%) women affected, followed by Candida spp. with 12,661 (10.61\%) and finally 2,023 with Trichomonas vaginalis (1.7\%). The mixed infection caused by Candida spp. with Gardnerella vaginalis was identified in 504 cases with Trichomonas vaginalis Gardnerella vaginalis in 172 cases, Candida spp. associated with Trichomonas vaginalis was identified in 52 cases and Candida spp. Gardnerella vaginalis associated with the presence of Trichomonas vaginalis in 07 cases, Table 1.

It was observed that 21,792 women reported using oral contraceptive, and among these ones, there was the presence of Gardnerella vaginalis in 1054 women, Candida spp. in 687 cases and 133 Trichomonas vaginalis. Regarding the use of copper intrauterine device, 18,894 women have it as a contraception method and there was no record of the presence of Gardnerella vaginalis in 964, Candida spp. and Trichomonas vaginalis in 595 in

Table 1. Occurrence of microorganisms in pap smears. Information System Cervical Cancer: SISCOLO, Sergipe, 2006-2010.

\begin{tabular}{|c|c|c|c|c|c|c|c|c|c|c|c|c|c|}
\hline Variables & 2006 & $\%$ & 2007 & $\%$ & 2008 & $\%$ & 2009 & $\%$ & 2010 & $\%$ & Total & $\%$ & p-valor* \\
\hline Total number of exams & 16550 & - & 27292 & - & 23983 & - & 27138 & - & 24349 & - & 119312 & - & \\
\hline Gardnerella Vaginalis & 2010 & 12.15 & 4162 & 15.25 & 2803 & 11.69 & 3402 & 12.54 & 3708 & 15.23 & 16137 & 13.52 & 0.001 \\
\hline Candida Spp. & 1705 & 10.3 & 3237 & 11.86 & 2061 & 8.59 & 2622 & 9.66 & 2996 & 12.3 & 12661 & 10.61 & \\
\hline Trichomonas Vaginalis & 385 & 2.33 & 517 & 1.89 & 405 & 1.69 & 392 & 1.44 & 317 & 1.3 & 2023 & 1.7 & \\
\hline $\begin{array}{l}\text { Gardnerella Vaginalis/ } \\
\text { Candida Spp. }\end{array}$ & 74 & 0.45 & 129 & 0.47 & 75 & 0.31 & 110 & 0.41 & 114 & 0.47 & 504 & 0.42 & 0.156 \\
\hline $\begin{array}{l}\text { Gardnerella Vaginalis/ } \\
\text { Trichomonas Vaginalis }\end{array}$ & 35 & 0.21 & 54 & 0.2 & 33 & 0.14 & 28 & 0.1 & 21 & 0.09 & 172 & 0.14 & 0.351 \\
\hline $\begin{array}{l}\text { Candida Spp./Trichomonas } \\
\text { Vaginalis }\end{array}$ & 8 & 0.05 & 11 & 0.04 & 13 & 0.05 & 10 & 0.04 & 10 & 0.04 & 52 & 0.04 & 0.655 \\
\hline $\begin{array}{l}\text { Gardnerella Vaginalis/ } \\
\text { Candida Spp./ } \\
\text { Trichomonas Vaginalis }\end{array}$ & 2 & 0.01 & 2 & 0.01 & 3 & 0.01 & 0 & 0 & 0 & 0 & 7 & 0.01 & 0.418 \\
\hline
\end{tabular}


Table 2. Use of pill or IUD associated with the presence of microorganisms. Information System Cervical Cancer (SISCOLO), Sergipe, 2006-2010.

\begin{tabular}{|c|c|c|c|c|c|c|c|c|c|c|c|}
\hline Variable & Microrganisms & 2006 & p-value* & 2007 & p-value* & 2008 & p-value* & 2009 & p-value* & 2010 & $p$-value* \\
\hline \multirow{3}{*}{ IUD } & Gardnerella & 131 & 0.01 & 288 & 0.01 & 247 & 0.01 & 259 & 0.01 & 39 & 0.02 \\
\hline & Candida Spp. & 62 & 0.01 & 187 & 0.01 & 139 & 0.19 & 187 & 0.01 & 20 & 0.01 \\
\hline & Trichomonas & 11 & 0.83 & 37 & 0.06 & 35 & 0.46 & 35 & 0.6 & 4 & 0.52 \\
\hline \multirow{3}{*}{ PILL } & Gardnerella & 136 & 0.45 & 310 & 0.27 & 257 & 1.3 & 274 & 0.01 & 77 & 0.05 \\
\hline & Candida Spp. & 74 & 0.01 & 210 & 0.33 & 150 & 0.56 & 204 & 0.08 & 49 & 0.04 \\
\hline & Trichomonas & 17 & 0.67 & 37 & $0.01 *$ & 35 & 0.62 & 39 & 0.31 & 5 & 0.59 \\
\hline
\end{tabular}

122, Table 2. The average age among women who had some kind of micorganisms considered potential infectious agent was $33.4 \pm 11.15$ years.

\section{Discussion}

Although the Pap test is not designed to diagnose the presence of microorganisms, its use for this purpose until the present day is a routine and remains controvsial $[12,13]$. When comparing its performance to that end, encouraging results are found in the diagnosis of Gardnerella vaginalis [10, 14].

The present study found the presence of Gardnerella vaginalis in pap smears in the years 2006, 2007, 2008, 2009 and 2010 with 12.15\%, 15.25\%, $11.69 \%, 12.54 \%$ and $15.23 \%$, followed by the yeast Candida spp. with $10.30 \%, 11.86 \%, 8.59 \%$, $9.66 \%$ and $12.30 \%$, finally showing Trichomonas vaginalis $2.33 \% 1.89 \% 1.69 \% 1.44 \%$ and $1.30 \%$ respectively for each year. These findings support those found in several regions of Brazil where Gardnerella vaginalis is the most pathogenic microorganism present in the female genital tract, compared with Candida spp. which was the second, followed by Trichomonas vaginalis through this technique [7, 15-17].

The infection caused by Gardnerella vaginalis is considered by some authors to be of sexual transmission [18], although this hypothesis is refuted by its presence in virgins school girls [8]. This type of disease has been associated with lack of proper sexual orientation, education, hygiene habits, early onset of sexual activity and multiple partners [2, 8-10]. On the other hand, the disequilibrium in the vaginal ecosystem, due to the rise in $\mathrm{pH}$ above 4.5 and a decrease or absence of colonization by lactobacilli, decrease of vitamin A, folate and calcium may be predisposing factors to the proliferation of microrganismo [6, 8, 19].

Like Gardnerella vaginalis, the presence of Trichomonas vaginallis can also be verified in Pap smear tests [20]. Its infection is considered a sexually transmitted disease, which risk factors are the number of sexual partners, socioeconomic status, personal hygiene, not using condoms and their association with other sexually transmitted diseases [21]. In pregnant women it can cause premature rupture of membranes and premature labor [7].

The colonization by Candida spp. is not generally well detected in Pap tests, due to its lower sensitivity when compared to the liquid médium [20, 22, 23]. In addition, the detection of Candida spp. in smear Pap tests is more difficult when the abnormal bacterial flora is also present or not when it comes to Candida albicans, which often do not make the pseudo-hyphae easily detected [9].

The so-called mixed infection in which there is presence of two or more potentially pathogenic microorganisms was detected in 735 tests. with a prevalence of the association bertween Gardnerella 
vaginallis and Candida spp., followed by GardnereIla vaginalis associated with Trichomonas vaginalis. One hypothesis for this finding may be related to a vaginal $\mathrm{pH}$ which is friendly to this type of colonizing [7].

The contraceptive use was identified in only $34.1 \%$ of all analyzed tests ( $n=119,312)$. The pill was the most reported with $18.2 \%$, followed by copper intrauterine device with $15.8 \%$. In other tests the type of contraceptive method was not identified. This lack of information is an obstacle to epidemiological studies aimed at using data from the Information System Cancer of the cervix (SISCOLO). Even with this difficulty, the data stored in this system represent an important resource for epidemiological studies, allowing the reduction of costs and time spent on research [24].

The use of the pill as the contraceptive method most commonly reported among women, reinforce studies $[6,16]$, which proves to be one of the most widely used, especially in northeast of Brazil. Research [25] on women's health in Brazil, showed that this type of contraception is one of the two most used methods.

Regarding the presence of microorganisms associated with the studied contraceptive use, the findings corroborate studies $[26,27]$ on the use of the pill and increased protection of women against any type of vaginal infection. However, the presence of copper intrauterine device is typically a promoter factor for bacterial $[6,28]$.

The average age of women who had some type of microorganisms was $33.4 \pm 11.1$ years, and this finding is similar to studies $[29,30]$ that highlight the second to fifth decades of life such as higher incidences for opportunistic infections of the vagina. In this study, the high standard deviation is justified by the large number of young people who underwent pap smear.

It was concluded that the greater frequency of Gardnerella vaginalis, followed by the presence of Candida spp. and Trichomonas vaginalis, denote the occurrence of mixed infections with evidence of three potentially pathogenic microorganisms. Regarding the use of contraceptives, the oral type is more used when compared with the copper intrauterine device. In the presence of microorganisms associated with the use of contraception, there is a greater frequency of Garnerella vaginalis in both types of contraception methods used by women. Note also that after ten years of implementation of SISCOLO, there are still many missing data, which hinders epidemiological studies, related to women's health to facilitate the most appropriate contraceptive gynecologists can state in order to prevent opportunistic infections.

\section{References}

1. Oliveira EH, Soares LF. Prevalência de vaginites infecciosas através da citologia clínica: um estudo no laboratório central de saúde pública do Piauí. Rev Bras Anal Clin. 2007; 39: 33-5.

2. Adad SJ, Lima RV, Savan ZT, Silva MLG, Souza MAH., Saldanha JC, et al. Frequency of Trichomonas vaginallis, Candida sp and Gardnerella vaginallis in cervical-vaginal smears in four different decades. Med Journal. 2001; 119:200-5.

3. Donders GGG, Mertens I, Bellen G, Pelckmans, S. Self-elimination of risk factors for recurrent vaginal candidosis. Mycoses. 2009; 54:39-45.

4. Castellano Filho DS, Diniz CG, Silva VL. Bacterial vaginosis: clinical, epidemiologic and microbiological features. HU Revista. 2010; 36:223-30.

5. Rosa MI, Rumel D. Fatores Associados à Candidíase Vulvovaginal: Estudo Exploratório. Rev Bras Ginecol Obstet. 2004; 26:65-70.

6. Leite SRRF, Amorim MMR, Calabria WB, Leite TNF, Oliveira, VS, Ferreira-Junior JAA, et al. Perfil clínico e microbiológico de mulheres com vaginose bacteriana. Rev Bras Ginecol Obstet. 2010; 32:82-7.

7. Bonfanti G, Gonçalves TL. Prevalência de Gardnerella vaginalis, Cândida spp. e Trichomonas vaginalis em exames citopatológicos de gestantes atendidas no Hospital Universitário de Santa Maria-RS. Rev Saúde. 2010; 36:37-46.

8. De La Calle IJ, De La Calle AJ. Vaginosis bacteriana. Med Clin. 2009; 133: 789-97.

9. Donders GGG, Berger J, Heuninckx H, Bellen G, Cornelis A. Vaginal flora changes on Pap smears after insertion of levonorgestrel-releasing intrauterine device. Contraception. 2011; 83:352-56. 
10. Karani A, Vuyst H, Luchters S, Othigo J, Mandaliya K, Chersich MF, Temmerman M. The Pap smear for detection of bacterial vaginosis. Int J Gynecol Obstet. 2007; 98:20-23.

11. Eriksson K, Forsum U, Bjornerem A, Platz-Christensen JJ, Larsson PG. Validation of the use of Pap-stained vaginal smears for diagnosis of bacterial vaginosis. APMIS 2007; 115:809-13.

12. Sodhani P, Garg S, Bhalla P, Singh MM, Sharma S, Gupta S. Prevalence of bacterial vaginosis in a community setting and role of the Pap smear in its detection. Acta Cytol. 2005; 49:634-8.

13. Tokyol C, Aktepe OC, Cevrioglu AS, Altindis M, Dilek FH. Bacterial vaginosis: comparison of Pap smear and microbiological test results. Mod Pathol. 2004; 17:857-60.

14. Discacciati MG, Simoes JA, Amaral RG, et al. Presence of $20 \%$ or more clue cells: an accurate criterion for the diagnosis of bacterial vaginosis in Papanicolaou cervical smears. Diagn Cytopathol. 2006; 34:272-6.

15. Silva-Brandão MB, Turmero GHC, Avila IIC. Análise de Vaginoses Microbianas em Pacientes Atendidas no Laboratório Central de Saúde Pública de Roraima. Norte Científico. 2010; 5:47-55.

16. Fernandes MFM. Mulher, família e reprodução: um estudo de caso sobre o planejamento familiar em periferia do Recife, Pernambuco, Brasil. Cad Saúde Pública. 2003; 19:253-61.

17. Tanaka VA, Fagundes LJ, Catapan A, Gotlieb SLD, Belda Júnior $W$, Arnone $M$, et al. Perfil epidemiológico de mulheres com vaginose bacteriana, atendidas em um ambulatório de doenças sexualmente transmissíveis, em São Paulo, SP. An Bras Dermatol. 2007; 82:41-6.

18. Demba E, Morison L, Loeff S, Awasana AA, Gooding E, Bailey $R$, Mayaud $P$, West B. Bacterial vaginosis, vaginal flora patterns and vaginal hygiene prac- tices in patients presenting with vaginal discharges syndrome in the Gambia, West Africa. BMC Infectious Diseases 2005; 5:1-12.

19. Neggers YH, Nansel TR, Andrews WW, Schwebke JR, Yu KF, Goldenberg RL, et al. Dietary intake of selected nutrients affects bacterial vaginosis in women. J Nutr. 2007; 137: 2128-33.

20. Takei H, Ruiz B, Hicks J. Cervicovaginal flora: Comparison of conventional Pap smears and a liquid-based thin-layer preparation. Am J Clin Pathol. 2006; 125:855-9.

21. Maciel GP, Tasca T, Carli-de GA. Aspectos clínicos, patogênese e diagnóstico de Tricomonas Vaginalis. J Bras de Patol Med Laborat. 2004; 40:152-60.

22. Audisio T, Pigini T, de Riutort SV. Validity of the Papanicolaou smear in the diagnosis of Candida spp., Trichomonas vaginalis, and bacterial vaginosis. J Low Genit Tract Dis. 2001; 5:223-5.

23. Engberts MK, Goedbloed AF, van Haaften M, Boon ME, Heintz PM. Microscopic diagnosis of vulvovaginal candidiasis in stained vaginal smears by Dutch general practitioners. Acta Cytol. 2007; 51:882-5.
24. Girianelli VR, Thuler LCS, Silva GA. Qualidade do Sistema de Informação do Câncer do Colo do Útero no estado do Rio de Janeiro. Rev Saúde Publica. 2009; 43:580-8.

25. Brasil. Ministério da Saúde. Pesquisa Nacional de Demografia e Saúde. Brasília, DF: Ministério da Saúde; 2006. http://bvsms. saude.gov.br/bvs/publicacoes/pnds crianca mulher.pdf

26. Hodoglugil NN, Aslan D, Bertan M. Intrauterine device use and some issues related to sexually transmitted disease screening and occurrence. Contraception. 2000; 61:359-64.

27. Wilson JD, Lee RA, Balen AH, Rutherford AJ. Bacterial vaginosis flora in relation to changing oestrogen levels. Int J STD AIDS. 2007; 18:308-11.

28. Ehrström SM, Kornfeld D, Thuresson J, Rylander E. Signs of chronic stress in women with recurrent candida vulvovaginitis. American J Obstet Gynecol. 2005; 193:1376-81.

29. Nai GA, Mello ALP, Ferreira AD, Barbosa RL. Frequência de Gardnerella vaginalis em esfregaços vaginais de pacientes histerectomizadas. Rev Assoc Med Bras. 2007; 53:162-5.

30. Larsson PG, Fahraeus L, Carlsson B, Jakobsson T, Forsum U. Predisposing factors for bacterial vaginosis, treatment efficacy and pregnancy outcome among term deliveries; results from a preterm delivery study. BMC Women's Health. 2007; 7:20.
Publish in International Archives of Medicine

International Archives of Medicine is an open access journal publishing articles encompassing all aspects of medical science and clinical practice. IAM is considered a megajournal with independent sections on all areas of medicine. IAM is a really international journal with authors and board members from all around the world. The journal is widely indexed and classified Q2 in category Medicine. 